Colloquia Litteraria

UKSW

$4 / 52008$

DOROTA KIELAK

\title{
MODERNISTYCZNY PALIMPSEST MODEL LEKTURY - FIGURA TOŻSAMOŚCI
}

Pojęcie palimpsestu, pojawiające się w literaturze przełomu XIX i XX wieku, zostało w oczywisty sposób zaprojektowane przez kryzys scjentystycznego myślenia. Teresa Walas używa go, pisząc o procesie nawarstwiania się w latach 90. XIX w. światopoglądu pozytywistycznego, naturalistycznego, a na nim w końcu dekadenckiego ${ }^{1}$. Palimpsestową naturę ma bowiem proces, w którym „tekst pozytywistyczny przeistoczył się w tekst naturalistyczny"2, a ten ostatni

\footnotetext{
${ }^{1}$ Ewa Ihnatowicz pisze: „Teresa Walas rozważając filozoficzne ramy dekadentyzmu używa słowa «palimpsest». Określa ono tekst naturalistyczny wygenerowany przez pozytywistyczny, a następnie tekst dekadencki nawarstwiony na tamtym. Palimpsestowość dekadentyzmu oznacza również ambiwalentność jego składników. Badaczka wskazuje, że dekadenckie poczucie kryzysu prawdy i możliwości poznawczych mogło nieść ze sobą nie tylko postawę rezygnacji z poszukiwania prawdy, ale także synkretyzm filozoficzny obecny w ogóle w modernizmie, postawę akceptacji wielości prawd" (E. Ihnatowicz, Młodopolski palimpsest w powieściach Michała Choromańskiego, [w:] Modernistyczne źródła dwudziestowieczności, red. M. Dąbrowski, A. Z. Makowiecki, Warszawa 2003, s. 131; p. 2).

${ }^{2}$ T. Walas, Ku otchłani (dekadentyzm w literaturze polskiej 1890-1905), Kraków-Wrocław 1986, s. 38. „Jak to się stało, że tekst pozytywistyczny został tak łatwo zdominowany przez naturalistyczny mimo jego pozornej nieatrakcyjności? Dlaczego widoczna w każdym światopoglądzie tendencja do ujednolicenia całości przybrała ten właśnie kierunek? Po pierwsze - i tu porównanie z palimpsestem okaże się przydatne - naturalizm był tekstem nowym, przez co bardziej wyrazistym, lepiej, by tak rzec, rzucającym się w oczy” (tamże, s. 39). „Aktywność tej świadomości [dekadenckiej] jest [...] ograniczona: może ona produkować takie jedynie zdania, na które tekst naturalistyczny zezwala i które dopuszcza. W istocie też w łonie tamtego tekstu kształtuje się powoli wypowiedź nowa, dla której naturalizm będzie modelującą ramą i wiązką
} 
następnie w tekst dekadencki. Ewa Ihnatowicz twierdzi, że rozważania badaczki są świadectwem tego, jak „,modernistyczne poczucie palimpsestowości tekstu znajduje swoiste potwierdzenie w opisującym je języku historii literatury"3. Odwracając problem, można powiedzieć, iż tenże język historii literatury - jako kształtowany w relacji z przedmiotem jej badań - najlepiej też świadczy o tym, że palimpsestowej figury wyobraźni, występującej w literaturze przełomu wieków, nie można odczytywać jedynie jako oderwanej od świadomości epoki i zuniwersalizowanej metafory wieloznaczności ${ }^{4}$. Figura palimpsestu została wygenerowana ze świadomości epoki jako integralnie związana z doświadczeniem kształtującym kulturową tożsamość tego pokolenia. Unaocznia ona proces zacierania się oraz zanikania podstawowego obszaru znaczeń tworzących światopogląd pozytywistyczno-naturalistyczny i dokonującego się w jego ramach procesu nadbudowywania płaszczyzny nowych sensów, które optymizm światopoglądowy scjentystów zamieniały w dekadencki pesymizm ${ }^{5}$. Wyobraża sytuację, w której „,tekst pozytywistyczny [...] przez samo swoje wyłonienie się, swoje, by tak rzec wybrzmienie wywoływał tekst kontradyktoryjny $[\ldots]$ ]. On też,

jako produkowany wewnątrz tej samej ramy modelującej, w odniesieniu do tej samej hierarchii wartości opiera się najwyraźniej na wzorze utajonego sporu: zdania, które się nań składają, tak są dobrane, by przeczyły zdaniom tekstu pozytywistycznego, pozornie zgadzając się z jego presupozycjami. $^{6}$

uznanych przesłanek" (tamże, s. 43).

${ }^{3}$ E. Ihnatowicz, dz. cyt., s. 131.

${ }^{4} \mathrm{~W}$ taki właśnie sposób pisze o palimpseście Ewa Ihnatowicz, choć jednocześnie wyraźnie zaznacza jego młodopolską proweniencję (por. tamże, s. 131-144). Także Krzysztof Mrowcewicz, pisząc o specyfice poezji Mikołaja Sępa Szarzyńskiego, przekonuje, że droga do odczytania palimpsestu ,nie wiedzie bynajmniej przez ich uporządkowanie i zhierarchizowanie, lecz przez zgodę na wieloznaczność" (K. Mrowcewicz, Sep palimpsestowy. Kilka uwag o stylu Mikołaja Sepa Szarzyńskiego, „Teksty Drugie” 2004, z. 3, s. 29).

${ }^{5}$ Por. T. Walas, dz. cyt., s. 38-39.

${ }^{6}$ Tamże, s. 40-41. 
Operowanie wyobrażeniem palimpsestu w odniesieniu do utworu literackiego z przełomu XIX i XX wieku jest też przede wszystkim stwierdzeniem jego semantycznej wielowarstwowości, tworzącej się w efekcie doświadczenia scjentystycznego kryzysu. Jest wskazaniem na ambiwalencję sensów, na wewnętrzne zdialogizowanie znaczeń poddanych procesowi przeobrażeń, wynikających z przemian światopoglądowych schyłku XIX wieku. W takiej roli wyobrażenie palimpsestu pojawia sięw pierwszej części Trylogii księżycowej Jerzego Żuławskiego Na srebrnym globie, w której palimpsestem nazwano pamiętnik powstały podczas międzynarodowej wyprawy na Księżyc. Palimpsest uczynił z niego młody naukowiec, który po pięćdziesięciu latach od chwili wystrzelenia statku kosmicznego poza orbitę ziemską odnalazł go i poddał obróbce pozwalającej na jego odczytanie.

Przypuszczałem - i jak się później okazało - słusznie, że atrament, którego użyto do pisma, zawierał składniki mineralne, a zatem zaczernione nim miejsca będą stawiały większy opór promieniom rentgenowskim niż sam zwęglony papier. Naklejałem tedy ostrożnie każdą kartę rękopisu na cienką błonę, rozpiętą w ramie, i robiłem rentgenowskie zdjęcia fotograficzne. W ten sposób otrzymałem klisze, które po przeniesieniu obrazu na papier dały mi rodzaj palimpsestów, gdzie litery, po obu stronach papieru pisane, łączyły się ze sobą. Było to trudne do odczytania, ale bynajmniej nie niemożliwe [podkreśl. - DK]. ${ }^{7}$

Przekształcenie pamiętnika w palimpsest przesądza o jego lekturze. $Z$ jednej strony mobilizuje do traktowania go jako świadectwa naukowej wyprawy, świadectwa scjentystycznej rodem wiary w nieograniczone możliwości poznawcze człowieka, a z drugiej - sprzyja postrzeganiu go jako dokumentu, który w swojej scjentystycznej ramie nosił zespół przekonań i przemyśleń dających możliwość refleksji zaprzeczającej temu optymizmowi. Palimpsestowy status rękopisu, czyli pamiętnika Jana Koreckiego - Polaka uczestniczącego w międzynarodowej wyprawie na Księżyc - daje możliwość poszukiwania obecnego

${ }^{7}$ J. Żuławski, Na srebrnym globie. Rękopis z Księżyca, przedm. S. Lem, posł. K. Kortylewski, Kraków 1956, s. 20. 
w nim zaufania do nauki jako jedynego źródła wiedzy o świecie, a tym samym wiary w ewolucyjny postęp i mądrość natury, którym sprzyjają też opisy monumentalności księżycowego krajobrazu, opisy terenów przypominających biblijny Raj z bujną roślinnościa, ze zwierzętami pozbawionymi instynktu zabijania oraz obfitymi deszczami, zalewającymi całą tę ziemię również podobnym do biblijnego potopem. Zabrana na pokład kosmicznego statku Biblia, a szczególnie Księga Genesis staje się dodatkowym atutem na rzecz stwierdzenia, iż bohaterowie tego exodusu nie tylko cechowali się niezachwianą wiarą w celowość praw natury, lecz także myśleli o nich wzniosłymi kategoriami. Zwęglony pamiętnik niewątpliwie stał się znakiem przeświadczenia, iż „człowiek przez swą rozumność zmierza ku dobru, a przyrost wiedzy pociąga za sobą przyrost moralności”". Jednocześnie jednak poprzez zawarte w nim relacje ,prześwieca” także prawda o tym, że

nie ma żadnego związku między rządzącymi naturą prawidłościami a moralnością; człowiek jest obiektem działania instynktów i praw biologicznych oraz odwzorowujących tamte praw społecznych niepodlegających kwalifikacji etycznej9.

Przekonania takie emanują z opisów oraz refleksji dotyczących szczególnie natury księżycowego społeczeństwa, które zostaje założone przez potomków Marty - Hinduski włączonej do załogi statku w ostatniej chwili. Księżycowa przestrzeń - która de facto stanowiła przecież miejsce zaspokojenia naukowych ambicji uczestników wyprawy, w tym znaczeniu też obszar ich scjentystycznej tożsamości, pozwalała im zgłębić mądrość praw natury - stała się jednocześnie miejscem życia ludzi doświadczających dezintegrującego procesu ewolucji, ludzi pod każdym względem „małych” - słabych fizycznie, niskich wzrostem, o ograniczonych przymiotach duchowych oraz intelektualnych, pozbawionych umiejętności abstrakcyjnego myślenia, krótko żyjących, zastraszonych, bezradnych, poddających się wszelkim „ziemskim” namiętnościom i egzystujących pod ciąłła presją

${ }^{8}$ T. Walas, dz.cyt., s. 41.

${ }^{9}$ Tamże. 
śmierci - w obawie przed nierozpoznanymi jeszcze mieszkańcami planety. Obecna w pamiętniku pesymistyczna wizja świata rodzi się wbrew intencjom jego autora, jest inkluzem scjentystycznej świadomości bohatera, który - „szaleństwem żądzy poznania obłąkany” ${ }^{10}$ - spędził na Księżycu większą część swojego życia. Rękopis staje się dokumentem pokazującym, jak ,tekst pozytywistyczny generuje z siebie swój wariant i swoje przeciwieństwo zarazem: naturalizm"11, a ten ostatni staje się podłożem dla zespołu twierdzeń rozsadzających jego spójność i - co najważniejsze - reinterpretujących jego podstawowe założenia. Można powiedzieć, cytując po raz kolejny Teresę Walas, że istotę tego dokumentu tworzy „współwystępowanie światopoglądów mieszczących się we wspólnej ramie, lecz wrogo do siebie nastawionych”, które „stwarza wrażenie pewnej dowolności”"12.

Palimpsest jest metaforą nietrwałości sensów, znakiem zacierania się ich wyrazistości w procesie długiego trwania. Jak pisze Walas, scjentystyczne prawdy po upływie czasu zniechęcały głównie tych, którzy „nie brali bezpośredniego udziału w ich formułowaniu”13, generując $\mathrm{z}$ siebie wartości rewidujące naukowy optymizm wcześniejszego pokolenia (warto podkreślić, że w powieści Żuławskiego księżycowy rękopis staje się palimpsestem odczytanym i podanym do publicznej wiadomości przez naukowca nazwanego znacząco „młodym” i reprezentującego kolejną generację). Rozciągłość w czasie scjentystycznych idei wyjaławia je i wpływa na nie dezintegrująco, pozwalając na tworzenie się w ich obrębie - zgodnie z palimpsestową logiką - nowych jakości światopoglądowych. Poczucie upływu czasu, rozpoznawanie świata w jego temporalnej perspektywie chwieje stabilnością aksjologicznej tożsamości, w której wyznawane idee - na skutek rozciągłości w czasie - tracą swoją jednoznaczność oraz klarowność.

\footnotetext{
${ }^{10}$ J. Żuławski, dz. cyt., s. 304.

${ }^{11}$ T. Walas, dz. cyt., s. 41.

12 Tamże, s. 42.

13 Tamże, s. 39.
} 
[...] Światopogląd ulega zużyciu przez samą rozciąłość w czasie, nawet w tych miejscach, w których nie przystaje do żadnej praktyki życiowej, nie podlega więc falsyfikacji przez ,sprawdzanie w życiu”. Prawdy oglądane zbyt długo w tej samej postaci, nie odwołujące się do żadnej poza ludzkim rozumem instancji, nużą i zniechęcają do siebie ${ }^{14}$.

- pisze Teresa Walas. Palimpsest staje się znaczącą figurą wyobraźni na przełomie wieków jako metafora kryzysowej - dekadenckiej świadomości, uzmysławiając jednocześnie fakt, iż gruntem, na którym tworzy się to młodopolskie doświadczenie kryzysu, jest taki dystans do przemian światopoglądowych drugiej połowy XIX wieku, który tworzy się na skutek doświadczenia upływu czasu.

Można byłoby powiedzieć, że palimpsest jest figurą ewolucyjnego poglądu na świat. Jednak utożsamienie określenia „długiego trwania" z pojęciem ewolucji byłoby w tym momencie zbyt daleko idącym uproszczeniem. Zmetaforyzowane za pomoca wyobrażenia palimpsestu przeświadczenie o czasowej dynamice wszelkich idei bardzo dobrze służy ewolucyjnym kategoriom myślenia o rzeczywistości, mobilizując jednak tym samym do przekroczenia ich granicy. Otwiera ono bowiem perspektywę rozważań o możliwościach odzyskania wartości, które uległy zacierającym je przeobrażeniom w toku dziejów, sprzyjając gestowi przywracania tego, co pozornie zaginione i niepochwytne, a faktycznie cały czas obecne, bo ukryte pod współczesnymi formami cywilizacji i czekające na ,wydobycie”. Jeśli wyobrażenie palimpsestu dobrze oddawało dekadencką świadomość, stając się figurą schyłkowości, to na tej samej zasadzie równie dobrze pozwalało na myślenie o tym, że - jak napisał Stanisław Przybyszewski w Requiem aeternam - „wsteczna metamorfoza może się rozpocząć”15. Wyobrażenie palimpsestu było transpozycją doświadczenia kryzysu na progu nowego wieku, automatycznie też otwierając perspektywę jego przezwyciężania. Palimpsestowy model lektury, czyli odczytywania - poprzez wysiłek rekonstrukcji - tego, co ukryte i zatarte, stawał się równocześnie

14 Tamże.

${ }^{15}$ S. Przybyszewski, Requiem aeternam, [w:] tenże, Wybór pism, oprac. R. Taborski (BN I 190), Wrocław 1966, s. 84. 
nakazem docierania do tego, co ,archaiczne” i ,pierwotne”, by nie tylko zbadać proces ewolucyjnego zatracania się wartości, ale przede wszystkim dotrzeć do źródeł ich reintegracji.

Nie bez znaczenia jest w tym kontekście fakt, że śmiałkowie w powieści Żuławskiego wyruszają właśnie na Księżyc, że celem ich naukowej penetracji nie staje się żadna inna planeta, na temat której wiedza pisarza mogłaby być równie imponująca ${ }^{16}$. Międzynarodowa ekipa ląduje jednak na Księżycu, gdyż to on właśnie - jak stwierdza bohater - stanowił wraz z Ziemią prajednię, przestrzeń tak wyraźnie nacechowaną w świadomości modernistów, którzy poszukiwali obszaru pierwotnego scalenia jako antidotum na doświadczenie rozpadu wartości współczesnej cywilizacji.

Ziemio! Daruj, iżem odszedł od ciebie, szaleństwem żądzy poznania obłąkany, którąś ty sama we mnie wychowała, uwiedziony srebrną twarzą tego globu martwego, któryś ty przed wiekami wyrzuciła ze siebie, aby nocom twym świecił i kołysał twoje morza! ${ }^{17}$

Palimpsestowy model lektury pozwala na odczytanie tej - na pozór wydawałoby się naukowej - informacji o jedności obu planet, która została rozerwana przed milionami lat, jako nowego sensu, wygenerowanego w starej ramie światopoglądowej. On też pozwala nadać całkiem nowy wydźwięk wspomnianym już skojarzeniom księżycowej fauny i flory z Rajem. W perspektywie myśli o księżycowej przestrzeni, jako swoistej namiastce - pozostałości utraconej prajedni, wizja księżycowego Edenu wydaje się tylko częściowo wspierać przeświadczenie o mądrości natury i jej etycznym nacechowaniu, wyrażając przede wszystkim tęsknotę za życiem w świecie nieskażonym

${ }^{16} \mathrm{~K}$. Kortylewski z wielkim uznaniem pisze o astronomicznych kompetencjach autora powieści: „Rzadko spotyka się dzieła fantastycznonaukowe, w których by pisarz wykazał tyle wysiłku w uzgodnieniu treści dzieła z faktami naukowymi, ile tego wysiłku znać w pierwszej części książki J. Żuławskiego Na srebrnym globie. Szczegółowa mapa powierzchni Księżyca, narysowana przez autora własnoręcznie, oparta jest na źródłach naukowych, ważnych do dnia dzisiejszego" (K. Kortylewski, Uwaga astronoma, [w:] J. Żuławski, dz. cyt., s. 331).

\footnotetext{
${ }^{17}$ J. Żuławski, dz. cyt., s. 304-305.
} 
cywilizacją i wiarę w możliwość uczynienia tejże tęsknoty rzeczywistością $^{18}$. I w tym momencie mamy do czynienia z pewnym paradoksem. Palimpsest, który kierował wyobraźnię w stronę idei regresu, nie redukował sam siebie, a przez to jeszcze bardziej wzmacniał swoją palimpsestową naturę. Otwierał bowiem perspektywę ,wyinterpretowania się" w ramach kształtującego go światopoglądu jeszcze jednej warstwy znaczeń, już nie dekadenckich, lecz te ostatnie wyraźnie przełamujących. Myślenie kategoriami palimpsestu znakomicie wyrażało chęć znalezienia dróg ucieczki od ewolucyjnej wizji rzeczywistości w afirmację mitu i właściwej temu mitowi idei „wiecznego powrotu" ${ }^{19}$. Palimpsestowy model lektury znosi dystans między tym, co dawne, a tym, co teraźniejsze. Otwierając perspektywę odczytywania tego, co chronologicznie odległe, można powiedzieć uaktualniania tego, co czasowo przebrzmiałe, dawał nadzieję stworzenia wspólnej płaszczyzny obecności dla zjawisk zróżnicowanych czasowo. Redukował napięcie towarzyszące ewolucyjnemu z ducha przekonaniu o tym, że współczesność kształtuje się w relacji z przeszłością, pozwalając na przekroczenie bariery czasu i logiki przyczynowo-skutkowego porządku dziejów. Inaczej mówiąc, sprzyjał odrzuceniu deterministycznej natury czasu na rzecz zakorzenienia się w „historycznym bezczasie"20, stawiając też mimochodem pytanie o zależność między

${ }^{18}$ Por. D. Trześniowski, Młodopolskie źródła fantasy. „Trylogia księżycowa” Jerzego Żuławskiego, [w:] Modernistyczne źródła dwudziestowieczności, red. M. Dąbrowski, A. Z. Makowiecki, Warszawa 2003, s. 202: „Biblia podpowiada język, w jakim podróżni opisują swoje doświadczenia. Ziemia urasta z wolna do rangi Raju Utraconego, cała wyprawa nazywana jest Exodusem, druga strona Księżyca, gdzie możliwe jest życie, jest Ziemią Obiecaną, Marta i Tomasz są prarodzicami nowego ludu księżycowego, wkrótce młodzi selenici przeżyją nawet swój potop - wóz kosmiczny spełni rolę arki Noego".

${ }^{19}$ Por. rozważania Teresy Walas na temat światopoglądu Stanisława Przybyszewskiego, który przebył właśnie taką drogę od ewolucyjnego myślenia o świcie do przekonania o kształtującym go procesie doskonalenia się „Duszy”. Wykonał „manewr światopoglądowy”, zastępując „mechanistyczną wizję natury i mechanicznie pojmowanego procesu ewolucji [...] wyobrażeniem odmiennym, spirytualistycznym, energetycznym i kreacjonistycznym", a także unieważniając „linearne wyobrażenie czasu oraz myśl o kresie ewolucji” (T. Walas, Przybyszewski a dekadentyzm, [w:] Stanistaw Przybyszewski. W 50-lecie zgonu pisarza: studia, red. H. Filipkowska, Wrocław 1982, s. 61-63).

${ }^{20}$ Określenie zaczerpnięte $\mathrm{z}$ rozważań Kazimierza Wyki na temat mitu w twórczości Władysława Reymonta (K. Wyka, Próba nowego odczytania „Chlopów” Reymonta, [w:] tenże, 
młodopolską fascynacją mitem a naturalistycznym podłożem przekonań epoki - zależność, która stała się też jednym z głównych problemów powieści Żuławskiego ${ }^{21}$.

W kontekście idei odrodzeńczych epoki należy rozpatrywać pojęcie palimpsestu, które znalazło się w podtytule Snów Marii Dunin Karola Irzykowskiego, jako tekstu otwierającego perspektywę odczytania treści ukrytych w jego strukturach głębokich, eksplikujących jednoczenie sensy Patuby.

Maria Dunin jest palimpsestem, to znaczy tyle, co mistyfikacją. Palimpsestem nazywają historycy pergamin, na którym wymazano jakieś pismo, aby na tym samym pergaminie napisać coś innego; w nowszych czasach udawało się za pomocą środków chemicznych wydobywać owe pierwotne pisma wsiąknięte w pergamin, a wówczas pokazywało się nieraz, że dawniejsze pismo zawiera treść ważniejszą niż nowsze. Podobnie jest i w Marii Dunin. Autor wypowiada oficjalnie przekonania, pod którymi należy dopatrywać się innych jego przekonań, wręcz przeciwnych tamtym. Ponieważ zaś przy końcu autor nawet i te drugie przekonania ujmuje w cudzysłów, przeto można powiedzieć, że Maria Dunin jest palimpsestem do kwadratu ${ }^{22}$.

- konstatuje Irzykowski, pisząc jednocześnie: „ideowej łączności Pałuby z Mariq Dunin odkryć nietrudno. Pałuba jest niejako wy-

Reymont, czyli ucieczka do życia, Warszawa 1979, s. 168. Wyka pisze, iż używając terminu „bezczas historyczny” „mówimy o bezczasie nie jako o naruszonej zasadzie lokalizacji dzieła w określonym kalendarzu historycznym, lecz przypisujemy mu określoną zawartość poznawczofilozoficzną. Taki bezczas to zamknięcie wydarzeń w powtarzalne koło i uznanie prymatu zasad służących kolistemu nawrotowi nad zasadami służącymi ich kierunkowemu przebiegowi”).

${ }^{21}$ Jest to pytanie ważne tym bardziej, że problem ten stał się w zasadzie przedmiotem rozważań w samej powieści Żuławskiego, rozpatrywanej łącznie w relacji z pozostałymi częściami Trylogii księżycowej. Stanisław Lem pisze, że pisarz drąży w trylogii zagadnienie genezy mitu jako kategorii ludzkiej świadomości: „rzeczywiste zdarzenie, heroiczny «Exodus » z Ziemi na Księżyc, zatracając swe ludzkie, realne oblicze, staje się w następnych pokoleniach przedmiotem kultu, zastygłym w symbole, znaki i obrzędy liturgiczne" (S. Lem, Przedmowa, [w:] J. Żuławski, dz. cyt., s. 6). Tejże problematyce poświęca swoje refleksje także D. Trześniowski, dz. cyt., s. 199-219, tezą swojego artykułu czyniąc stwierdzenie, iż ,nadrzędną kategorią organizująca porządek świata przedstawionego Trylogii księżycowej pozostaje mit [...]" (tamże, s. 201).

${ }^{22}$ K. Irzykowski, Pałuba. Sny Marii Dunin, oprac. A. Budrecka (BN I 240), Wrocław 1981, s. 466 (Wyjaśnienie ,,Snów Marii Dunin”). 
konaniem programu, wypełnieniem ram mglisto zarysowujących się w Marii Dunin"’23. W przytoczonych wyżej fragmentach Wyjaśnienia „Snów Marii Dunin” pojęcie palimpsestu (którego bohaterem, warto podkreślić na marginesie, jest archeolog, czyli ten, którego zawodowym powołaniem jest poszukiwanie ,znaczeń" ukrytych pod kolejnymi „warstwami” dziejów) zostało wyraźnie użyte na określenie specyfiki tekstu ustanawiającego reguły interpretacji powieściowej całości, nazwanej przez badaczy ,,jedyną w polskiej literaturze tak poważną próbą «naturalizmu konsekwentnego», która dąży do sformułowania nowej koncepcji prawdy artystycznej" ${ }^{24}$. Irzykowski - jak pisze Ewa Paczoska - zafascynowany twórczością niemieckich naturalistów, m.in. „naturalisty konsekwentnego” Arno Holza, o którym pisał, iż „dał próbę kinematografii duszy”, ,,przesuwające się przez zwierciadło duszy wrażenia z zewnętrznego świata, rodzące się w związku lub bez związku z nim skojarzenia myślowe i czuciowe” związawszy „razem w pozornie bezładny, a jednak misternie ułożony bukiet"25, na samym wstępie swojego dzieła, za pomocą wyobrażenia palimpsestu, ustanowił zasadę jego lektury otwartej na konstrukcje nacechowane wielością sensów. Jest to wielość w znaczeniu ich paradoksalności („Autor wypowiada oficjalnie przekonania, pod którymi należy dopatrywać się innych jego przekonań, wręcz przeciwnych tamtym"26) oraz ich wielowarstwowości. Tworząc projekt poszukiwania sensów w przestrzeni ambiwalencji znaczeń, na styku twierdzeń przeciwstawnych, zaproponował zasadę interpretacji „zstępującej”, czyli takiej, którą określa gest „schodzenia w głąb”, rozumianego jako poszukiwanie sensu utworu w spotkaniu z tajnią podświadomości zarówno bohatera, jak i autora. Takiemu gestowi sprzyjałoby odwołanie do dzieł Sigmunta Freuda, którego znakiem w utworze jest postać pana Acheronta Movebo, ojca

${ }^{23}$ Tamże, s. 457.

${ }^{24}$ E. Paczoska, Tajemnice „,Pałuby”, [w:] J. Kulczycka-Saloni, D. Knysz-Rudzka, E. Paczoska, Naturalizm i naturaliści w Polsce. Poszukiwania, doświadczenia, kreacje, Warszawa 1992, S. 232 .

${ }^{25}$ K. Irzykowski, Niezrozumialcy, [w:] tenże, Czyn i słowo. Pisma, red. A. Lam, Kraków 1980, s. 436, cyt. za: E. Paczoska, Tajemnice „Pałuby”, s. 232.

${ }^{26}$ K. Irzykowski, Pałuba. Sny Marii Dunin, s. 457. 
Marii Dunin, bohatera o imieniu i nazwisku utworzonym ze zbitki dwóch słów pochodzących z fragmentu Eneidy Wergiliusza, wykorzystanego przez słynnego psychiatrę jako motta do opublikowanej w 1900 r. Teorii snów ${ }^{27}$. Irzykowski zaproponował zasadę interpretacji, którą najlepiej sformułował Kazimierz Wyka, odczytując palimpsestowy projekt lektury Pałuby i nazywając ją całością wielopoziomową, złożoną z powieści właściwej, quasi-powieści analitycznej oraz quasi-powieści o powieści ${ }^{28}$. Ta interpretacja też bardzo dobrze egzemplifikuje jeden z najważniejszych postulatów krytycznych autora $C z y n u$ i słowa - postulatu docierania do prawdy o człowieku poprzez zdzieranie masek obłudy, odrzucanie kolejnych płaszczyzn psychologicznego zafałszowania ${ }^{29}$. Wpisany w dzieło Irzykowskiego palimpsestowy model lektury wyraźnie sytuuje powieść w obszarze idei odrodzeńczych epoki, które realizowały się w niej jako postulat reintegracji człowieka, jego uzdrowienia w geście odkrywania wszystkich etapów jego zafałszowań, a tym samym też odrodzenia literatury, odnawianej w akcie przekraczania bariery konwencjonalności.

Powieści Żuławskiego oraz Irzykowskiego są utworami, w których pojęcie palimpsestowości tekstu literackiego zostało wyeksponowane

${ }^{27}$ Zob. K. Irzykowski, Pałuba...., s. 8.

${ }^{28}$ K. Wyka, Młoda Polska, t. II: Szkice z problematyki epoki, Kraków 1987, s. 198: „Pałuba składa się z kilku jednocześnie książek. W jej powieściowy tekst wpisanych zostało kilka powieści. Pisząc te słowa, na myśli mam nie tylko układ nadany jej przez Irzykowskiego: palimpsest Marii Dunin, studium biograficzne Pałuba, komentarze do tych obydwu partii, i jeszcze komentarze.... Na myśli mam również to, że główny trzon dzieła, studium biograficzne o Piotrze Strumieńskim i jego dwóch małżeństwach, mieści w sobie istną plecionkę kilku powieści naraz pisanych, ale nie zawiera ani jednej powieści naprawdę dopełnionej. I chcąc Pałubę zrozumieć i ocenić, trzeba najpierw wydzielić z niej te powieści odrębne, przyjrzeć się im kolejno i z osobna, a później spróbować odtworzyć mechanizm, według którego Irzykowski każe się im zazębiać."; „W główną partię Pałuby wpisane zostały trzy książki: normalna powieść o dziejach podwójnego małżeństwa Piotra Strumieńskiego; analityczny traktat odautorski na temat tej powieści; książka warsztatowa o pisaniu utworu. Powieść właściwa, quasi-powieść analityczna, quasi-powieść o powieści" (tamże, s. 209).

${ }^{29}$ Irzykowski postulował poszukiwanie prawdy przez „rozumowe jej doznawanie”. „[...] we freudyzmie podobał się Irzykowskiemu pomysł, że najgorsze jest «zło utajone, nieświadome». «Chodzi więc o to» - pisał więc dalej o tym - «czy ludzie zdołają zdobyć momenta do uświadomienia, a więc zniszczenia tego zła». Kwestia etyki wiąże się tu ściśle z problemem epistemologicznym" (W. Głowala, Sentymentalizm i pedanteria. O systemie estetycznym Karola Irzykowskiego, Wrocław 1972, s. 35). 
jako klucz do ich odczytania. Można powiedzieć, że stało się ono elementem autotematycznej refleksji wpisanej w te utwory. Jak to zostało jednak stwierdzone na wstępie tego artykułu, figura palimpsestu wyrosła ze świadomości epoki jako integralnie związana z doświadczeniem kształtującym jej kulturową tożsamość. W tej sytuacji oczywiste wydaje się stwierdzenie, iż rozpatrywanie problemu palimpsestowego modelu lektury pozwala wyjść poza obręb refleksji autotematycznej, wyznaczającej kierunek interpretacji wskazanych utworów literackich z przełomu XIX i XX wieku, i zastanowić się nad nim jako ustanawiającym rygory myślenia nie zawężające się do interpretacji konkretnych wypowiedzi literackich, choć w nich wyraźnie się ujawniające. Tak jak stwierdzenie, że palimpsestowa wyobraźnia epoki uformowana została na przekonaniu o temporalnym uwarunkowaniu wszelkich idei, pozwoliło na znalezienie jej miejsca w młodopolskich projektach odrodzeńczych, tak też to samo przekonanie o roli palimpsestowej wyobraźni w artykulacji idei przełamujących dekadencki pesymizm otwiera perspektywę dla rozpatrywania jej już nie tylko jako ustanawiającej rygory interpretacji pojedynczego utworu, ale przede wszystkim jako tworzącej wzorzec postaw ujawniających się w sferze literackiej eksplikacji. Sfunkcjonalizowanie wyobrażenia palimpsestu w obszarze refleksji etycznej przełomu XIX i XX wieku, uczynienie go symbolem dążeń do odzyskania wartości zatartych $\mathrm{w}$ procesie ewolucyjnych przemian $\mathrm{w}$ pewien sposób narzuca rozpatrywanie tego wyobrażenia także jako figury kulturowej świadomości przełomu wieków. Palimpsestowy model lektury - projektując postawę wirtualnego odbiorcy - otwierał przed nim perspektywę intelektualnej konfrontacji z wielością artystycznych sensów, której istotą był wysiłek ich ,uporządkowania i zhierarchizowania" ${ }^{30}$ nie tylko w odniesieniu do świata literackich znaczeń, ale przede wszystkim w odniesieniu do odsłaniającego się w nim etycznego horyzontu epoki.

W literaturze początku XX wieku palimpsestowa wyobraźnia - w takim właśnie znaczeniu figury tożsamości - daje o sobie znać najwyraźniej w opisach miejskiej przestrzeni. Miasto, zwłaszcza o historycznym znaczeniu - jako obszar, na którym upływ czasu zapisuje się trwale

\footnotetext{
${ }^{30}$ Por. przypis 4.
} 
w nawarstwiających się stylach architektonicznych - w oczywisty sposób najlepiej poddawało się próbie interpretacji rekonstruującej przebrzmiałe dzieje pod kolejnymi warstwami historii. Cezary Jellenta $\mathrm{w}$ zapiskach $\mathrm{z}$ podróży po Umbrii $\mathrm{w}$ taki właśnie sposób postrzega Asyż, który zachwyca go specyfiką swego ukształtowania, sprawiającego wrażenie piętrowo nawarstwiających się ruin, zapraszającego podróżnika do przemierzenia „owych szarych kup gniazd czy kryjówek przylepionych hen wysoko do równie szarych pochyłości”, do zbadania „kamiennych miast i osad, z pozoru i widzianych z daleka pustych i niemych, jak zwaliska - wewnątrz zaś rojnych, rozgrzanych i głośnych"31. Jellenta, pokonując asyskie szlaki, tropi ślady zamierzchłej przeszłości. Co charakterystyczne, początkiem swojej refleksji odsłaniającej kolejne warstwy historii czyni najstarszą część miasta, w której znajduje się „potężna warownia, zburzona do połowy”32.

Trzyma się jeszcze olbrzymi trzon środkowy, kolosalny monument dawnych i jeszcze przedlongobardzkich czasów. Opasujące go i wielkim kręgiem zatoczone mury ciągną się od jednej baszty do drugiej całe staje. W skróceniu perspektywicznym piramida ta złożona $\mathrm{z}$ redut, $\mathrm{z}$ wież, szkarp i krużganków, domagających się żywo, aby je i dzisiaj jeszcze zużytkowano. Przyzwyczajono się uważać je za system naturalnych opok, za przypadkową symetryczną konfigurację skał raczej, niż za dzieło rąk ludzkich i nazywać: Rocca maggiore ${ }^{33}$.

Ruiny warowni Jellenta w symboliczny sposób utożsamia z tą pierwotną płaszczyzną architektonicznego palimpsestu, która w kolejnych wiekach zapełniona została następnymi, nakładającymi się na siebie „zapisami”. Sprzyja temu zwrócenie uwagi na warownię już na samym początku relacji, a także wyeksponowanie faktu, iż tworzy ona „punkt najwyższy, królujący nad Asyżem”34, a więc widoczny z daleka, przyciagający wzrok i wyznaczający drogę poznania, definiujące-

\footnotetext{
${ }^{31}$ C. Jellenta, Z ziemi umbryjskiej. (Notatki z podróży), „Literatura i Sztuka” 1912, nr 1, s. 3.

${ }^{32}$ Tamże.

${ }^{33}$ Tamże.

${ }^{34}$ Tamże.
} 
go się w tej sytuacji jako wznoszenie się w górę, można metaforycznie powiedzieć - jako wzrastanie ku niebu. Wskazanie tego najwyższego i jednocześnie najstarszego punktu jest zapowiedzią odkrywania palimpsestowej struktury miasta.

Wędrówka, rozpoczynająca się u podnóża stoku, na którym rozciąga się miasto, ku temu najodleglejszemu w czasie i centralnemu - w znaczeniu podstawy, na którą nałożyły się kolejne ,zapisy” historii - miejscu, będzie też szukaniem pod dziewiętnastowiecznymi warstwami architektury jej renesansowych, a w końcu i rzymskich pozostałości.

Każde wyjście na miasto jest nagrodzone nowym nabytkiem i nową pięknością, która olśniewa i wzrusza swą cichością i ukojeniem. Co krok, to pyszna, wysoka brama sklepiona, nad jakąś gospodą lub śpichlerzem, tuk śmiały i ciekawy, i zda się grożący runięciem. To jedna z wielu bram miejskich, sędziwa, a krzepka, romantycznie feudalna. Co chwila we fasadach domów zamurowane starożytne okna z charakterystycznym, łagodnym ostrołukiem zarania renesansu. Widać, że domy dzisiejsze pobudowano z dawnych. Nie rzadko spotyka się złomy trawertynu, z dawnych gmachów rzymskich, ciosane teraz przez kamieniarzy na materiał dla domów nowych. ${ }^{35}$

Wznoszenie się ku górze pozwala odkryć jeszcze starszą tradycję asyskiej przestrzeni - ukształtowaną w czasach helleńskich świątynię Minerwy.

Trudno opisać, jakiego się doznaje wrażenia na widok placu głównego, dzisiaj, jak wszystkie we Włoszech place większe - nazwanego «Vittorio Emanuele». Wchodzisz tam znagła, nieprzygotowany zgoła na większą przestrzeń i stając prawie na wprost dziwnego gościa. Tak - gościem tutaj wydaje się, przypadkową osobliwością ten, co był gospodarzem - fronton świątyni Minerwy. Poutrącane i poszczerbione od góry do dołu kolumny korynckie, wtłoczone między gmachy późniejsze, od razu momentalnie każą zapomnieć o wszystkim. W chaosie średniowiecza stoi ten niespożyty monument jakby regulator, wzór piękna i harmonii. Od razu wobec niego wszystko inne szarzeje, jak dowolność wobec konieczności, kaprys lub przygoda wobec wiekuistości prawa, igraszka wobec odwiecznego kanonu ${ }^{36}$.

\footnotetext{
${ }^{35}$ Tamże, nr 2, s. 19.

${ }^{36}$ Tamże, s. 20-21.
} 
Kres wędrówki po asyskim palimpseście wieńczy ostatecznie odkrycie ostatniej - i w tym sensie prawdziwie pierwotnej - warstwy, tworzącej grunt dla następujących w czasie „zapisów” historii. Tworzy ją przyroda.

Tutaj dopiero rozumie się prawdziwie wielką architekturę, jak to ona stała się normalnym dalszym ciągiem przyrody, plastyczną, posłuszną, a jednak zwycięską pokrywą wierzchnią terenu ${ }^{37}$.

Umbryjska natura - można pokusić się o taką metaforę - stanowi tę pierwotną „ramę światopoglądową”, w obrębie której wygenerowały się późniejsze teksty kultury, świadczące o coraz wyraźniejszym procesie cywilizacyjnego zakłócania pierwotnej harmonii człowieka $\mathrm{z}$ natura. Jellenta, odnajdując centrum tego labiryntu, a tym samym docierając do pierwotnego zapisu asyskiego palimpsestu, stwierdza, że tu właśnie

ani na chwilę nie ma do nas przystępu uczucie osamotnienia lub gorzkiego w pancerz zakutego wyniesienia się ponad świat i przyrodę. Jest się z nią zbratanym, zespolonym; władasz nią w pełni miłości i zachwycenia. Pieścisz i jesteś nawzajem pieszczony ${ }^{38}$.

Wyjaśnia się w tym momencie również to, dlaczego wędrowanie zgodnie z logiką palimpsestowej wyobraźni realizuje się w tym szkicu jako wznoszenie się ku górze. Z góry oczywiście rozciąga się najpiękniejszy widok na okolice miasta:

Szczęśliwi, co tu mieszkają! Szczę́sliwi, co stąd wzrokiem obejmują dolinę umbryjską! Choćby nawet kretynami byli, musieliby ją rozumieć, choćby serc nie mieli, musieliby ją kochać i w jej przestworzu się roztapiać3 ${ }^{39}$.

Ale idea wędrowania ku górze w intencji odnalezienia tego, co najgłębiej ukryte pod warstwą dziejów, ma tutaj swój szczególny sens.

\footnotetext{
37 Tamże, s. 19.

${ }^{38}$ Tamże, nr 1, s. 4.

${ }^{39}$ Tamże, nr 4, s. 55.
} 
Zawartą w swojej logice aksjologią utwierdza w statusie, jaki w młodopolskiej świadomości miała natura - natura rozumiana jako pierwotna duchowo-materialna jednia, natura uspirytualizowana i nacechowana etycznie ${ }^{40}$. Pozwala także ponowić sformułowaną wcześniej myśl o tym, że młodopolski palimpsest unaocznia tak ważną dla modernistów ideę regresu, rozumianego jako wyzwalanie reintegrującej mocy pierwotności.

Palimpsestowa świadomość ujawnia się w geście postrzegania świata jako struktury wielowarstwowej, mobilizującej do jej wartościującego odczytania. Należy jednak pamiętać, że na mocy tej samej logiki palimpsestowa świadomość manifestuje się także poprzez praktykę odczytywania i rozpoznawania wartości jako usytuowanych w tejże strukturze, zajmujących w niej określone miejsce. Palimpsestowe kategorie świadomości ujawniają się w postawie poszukiwania wartości jako tych, które trzeba odzyskać, tzn. wydobyć spod pokładów zacierającej je historii. Palimpsestowa świadomość każe wydobyć idee spod nawarstwiających się nad nimi obszarów cywilizacji oraz ludzkiej myśli. Stwierdzenie to bardzo dobrze też ilustruje analizowana relacja Jellenty. Stanowiące o jej oryginalności myślenie o Asyżu kategoriami palimpsestu okazuje się przygotowaniem refleksji o św. Franciszku. Przywołanie jego postaci jest zwieńczeniem tej wędrówki ,zstępującej” ku źródłom asyskich dziejów, choć przecież nie jest on postacią pierwszą - w znaczeniu chronologicznym - dla historii miasta. Nie bez powodu wspomnienie postaci Świętego pojawia się jako wyraźna konsekwencja myśli o powinowactwie architektury Asyża z jego naturą. Stwierdzenie, że architektura tego miasta jest ,dalszym ciagiem przyrody" stało się zapowiedzią rozważań o duchowości franciszkańskiej.

Nie tylko plastyka i krajobraz tego miasta utrzymuje w napięciu wszystkie władze ciekawości i kontemplacji, lecz i dwa bieguny jego historii.

\footnotetext{
${ }^{40},[. .$.$] młodopolskie doznanie Jedni dokonuje się w formie stopienia się, identyfikacji$ z naturą". (M. Podraza-Kwiatkowska, Młodopolskie doświadczenie transcendencji, [w:] taż, Wolność i transcendencja. Studia i eseje o Młodej Polsce, Kraków 2001, s. 78). Por. też M. Podraza-Kwiatkowska, Obraz Boga wśród światopogladowych przemian Młodej Polski, [w:] tamże, s. 104.
} 
Wspomnijmy, że tu się urodził nie tylko jeden z najbardziej oryginalnych i twórczych umysłów chrześcijańskich, św. Franciszek, a w dwanaście lat później jedna z najniezwyklejszych kobiet, św. Klara, lecz także i sławny poeta łaciński Propercjusz ${ }^{41}$.

Wraz z tym wspomnieniem wyraźna staje się wewnętrzna organizacja wypowiedzi Jellenty, który - poddając Asyż palimpsestowej lekturze, odkrywając kolejne pokłady jego kulturowego bogactwa - otwiera sobie perspektywę dla wyeksponowania osoby Świętego.

Ze starych murów wykwitające młode życie, przyszłość spokojnie i swobodnie strzelająca z przeszłości, która, zdawałoby się, zamknęła raz na zawsze swoje posłannictwo - to jedna $z$ najprzyjemniejszych niespodzianek i jedno z zwieńczeń Asyżu. A zarazem przypomina się wobec tych młodych minstrelów wielki niepoprawny trubadur, który wiekopomne swoje krystalizacje duchowe przeplatał śpiewaniem pieśni francuskich i również grą na gitarze. Był to sam św. Franciszek, ptak głosem natchnionym opiewający chwałę stworzenia. Do niego stale wraca myśl, rwąca się na krótko ku sprawom i zajściom aktualnym, albo i starożytnym jeszcze, przedchrześcijańskim. Pogoda i dobrotliwość przyrody Asyżu nasuwa bezustannie domysł, przypuszczenie, może bezzasadne, że ona pomogła duchowi jego ukształtować się tak właśnie a nie inaczej, że zachodzi związek przyczynowy między duszą tej ziemi, a duszą świętego poety. Mam wrażenie, że te gaje i doliny dają nam zrozumienie jego niesłychanej ekstatycznej natury. Tu pojmuje się lepiej jego bezprzykładne bratanie się ze światem roślinnym i zwierzęcym, jego miłość dlażywiołów, dla słońca i gwiazd, dla dniai nocy, chmuri jasności, ognia i dżdżu, dla wszystkiego, co jest stworzone przez Boga, i wreszcie dla śmierci samej. W nich czuł on braci i siostry, jak gdyby sam był skrzydlatym jak ptak lub wicher, a zwiewnym jak zapach lilii lub okiście kwiecia majowego. Tutaj można zrozumieć jego dwie zaciętości, na pozór tak sprzeczne $\mathrm{z}$ dogmatem pokory i posłuszeństwa: zaciętość $\mathrm{w}$ umiłowaniu swobody i zaciętość w rozwiązywaniu zagadki świata i bytu samą-li przeczystą dobrocią ${ }^{42}$.

\footnotetext{
${ }^{41}$ C. Jellenta, $Z$ ziemi umbryjskiej....., nr 2, s. 20.

${ }^{42}$ Tamże, nr 4, s. 55-56.
} 
Franciszkańskie idee, wpisujące się w aksjologiczny projekt epoki, uzyskały w szkicu Jellenty ,palimpsestową tożsamość”. Chociaż myślenie o franciszkańskiej postawie jako fundamentalnej dla europejskiej kultury, bo pozwalającej na kształtowanie jej świata wartości $\mathrm{w}$ oparciu o idee pierwotnej harmonii porządku ducha i materii, utworzyło na przełomie wieków jeden $\mathrm{z}$ ważniejszych tropów w recepcji postaci Świętego ${ }^{43}$, to w notatkach Jellenty uzyskało ono autonomiczny sens. Palimpsestowy model lektury franciszkańskich idei nie tylko zwracał uwagę na ich wartość, ale przede wszystkim problematyzował kwestie ich poznania. Przenosił punkt ciężkości z obszaru rozważań na temat ich aksjologicznego fenomenu na zagadnienie samego procesu ich wydobywania spod patyny wieków, a więc aktu ich rozpoznawania.

Palimpsestowy model lektury odzwierciedlał świadomość kryzysu, świadomość wyjaławiania się wartości kultury w ich czasowym przebiegu, ale także - a może przede wszystkim - odsłaniał szczególne uwrażliwienie modernistów na zagadnienie poznania, poszukiwania znaczeń w świecie, którego aksjologiczna wyrazistość zaciera się $\mathrm{w}$ procesie nieustających przemian. Tłumaczył tym samym sens poszukiwania kulturowych znaczeń jako przylegających do różnych światopoglądów, zawłaszczanych przez idee należące do odmiennych kręgów kulturowych oraz perspektyw czasowych. Sugerował prawo odczytywania kulturowych znaczeń przez pryzmat różnych systemów filozoficznych, pokazywania ich jako stapiających się z różnymi orientacjami światopoglądowymi, inaczej mówiąc: otwierał perspektywę kulturowego synkretyzmu w poszukiwaniu wartości. Nie bez powodu palimpsestowa figura świadomości ujawniła się w rozważaniach o mieście św. Franciszka, jego postać bowiem stała się na przełomie wieków takim właśnie przedmiotem interpretacji, poszukującej prawdy o świętym poprzez umieszczanie go w konstelacji różnych nurtów świadomości, włączanie jego duchowości w obszar doktryn nawet z definicji przeciwstawnych franciszkańskiemu ideałowi pokory, ubó1910 .

${ }^{43}$ Por. np. T. Garbowski, Św. Franciszek z Asyżu w świetle filozofii przyrodniczej, Kraków 
stwa i jedności wszelkiego stworzenia. Odkrycie w 1818 r. doczesnych szczątków Franciszka Bernardone, a w 1850 r. także i św. Klary ${ }^{44}$, pod koniec tego samego wieku stało się impulsem do refleksji przywracającej niekwestionowaną rangę wartości - które Poverello wniósł swoją postawą zarówno do dziejów Kościoła, jak i do kultury - poprzez ich sfunkcjonalizowanie w nurcie współczesnych dylematów i poszukiwań światopoglądowych. Duchowość św. Franciszka stała się czytelna przez pryzmat idei antymieszczańskiego buntu, modernistycznego postulatu wiary poza instytucją Kościoła, „wiary przełamującej przymus, wyzwalającej aspiracje jednostki" "45. Postać Świętego ożywała poprzez - tak istotne dla nurtów odrodzeńczych literatury przełomu wieków - idee

na nowo sformułowanej radości życia, akceptacji świata, czy raczej kontr-świata, przeciwstawianego porządkowi cywilizacji”, „odkrywania urody zwyczajnej egzystencji, piękna codzienności, walorów ludowego prymitywu ${ }^{46}$.

Znaczenia nabierała w końcu również w kontekście modernistycznego dyskursu o artystycznym indywidualizmie ${ }^{47}$ oraz „,nietzscheańskiej idei panowania nad sensem i tokiem dziejów"48.

Palimpsestowy model lektury - zarówno ten realizujący się w geście odnajdywania rygorów literackiej konstrukcji, jak i ten pozwalający na odczytywanie świata - ujawnia przekonanie modernistów o tym, że wartości trzeba poszukiwać nie jako danych i stałych, ale w ich historycznej zmienności, czujnie tropić je w labiryncie czasu. Użycie metafory labiryntu nie jest też w tym kontekście przypadkowe. Nie bez

${ }^{44}$ Zob. Z. Kijas OFMConv, Duchowość franciszkańska XIX i XX wieku, [w:] Dzieło św. Franciszka z Asyżu. Projekcja w kulturze i duchowości polskiej XIX $i$ XX wieku, red. D. Kielak, J. Odziemkowski, J. Zbudniewek, Warszawa 2004, s. 15.

${ }^{45}$ D. Trześniowski, Modernistyczny wizerunek buntownika, [w:] dz. cyt., s. 188.

${ }^{46}$ Tamże, s. 200.

${ }^{47}$ Zob. U. Kowalczuk, „Profile” świętego Franciszka - wersja Leopolda Staffa i Bolesława Leśmiana, [w:] Dzieło św. Franciszka z Asyżu... s. 201-218.

${ }^{48}$ D. Kielak, Franciszkanizm w projekcie polskiej tożsamości, [w:] tamże, s. 249. 
powodu bowiem właśnie $\mathrm{z}$ labiryntem skojarzona została $\mathrm{w}$ relacji Jellenty przestrzeń Asyżu. Pisarz, relacjonując swoją wędrówkę po zaułkach tego szczególnego miejsca, nie stroni od uwieczniania wrażeń, które bardzo wyraźnie sugerują porównanie wąskich uliczek miasta $\mathrm{z}$ trasą labiryntu

Ulice wąskie i jeszcze węższe przecznice, lada chwila, zda się, wyprowadzą na zamiejskie błonia. Powietrze, zagęszczone między wysokimi domami, nie obiecuje rzeczy szerokich. [...] Jednakże sieć ta, chociaż nieraz męczy, to zmusza to piąć się w górę, to schodzić po stopniach w dół, jednocześnie wciąga w siebie i podnieca [podkreśl. - DK. $]^{49}$.

W tej właśnie wypowiedzi bardzo dobrze widać, jak myślenie kategoriami palimpsestu znakomicie komponuje się z labiryntową wyobraźnią. Odczucie miejskiej aglomeracji jako sieci poplątanych uliczek, tworzących pewien rodzaj pułapki - wciagającej, odurzającej i zmuszającej do nieustającego biegu - pozwala wędrowcowi w sposób niemal sensualistyczny doświadczyć piętrowego układu Asyżu:

[...] ulice pną się jedna nad drugą aż prawie po sam szczyt warowny góry. [...] Unieś głowę, a ujrzysz nad sobą ogrody, winnice, wirydarze, ganki balkony. Wiele budynków prastarych i na pół walących się, a zamieszkałych przez biedotę, posiada na górnym piętrze cudowne «loggia», których by im, dla szlachetnego rysunku, pozazdrościć mógł niejeden pałac książęcy ${ }^{50}$.

Wrażenie zagubienia w labiryncie ulic uwrażliwia na przeżycie ich palimpsestowej struktury. Próba rozpoznania przestrzeni miasta w jej wymiarze horyzontalnym w naturalny sposób pociaga za sobą chęć opisania jej w porządku wertykalnym, a labiryntowa pułapka okazuje się wtajemniczeniem w kształtującą miejski pejzaż, nawarstwiają-

\footnotetext{
${ }^{49}$ C. Jellenta, Z ziemi umbryjskiej nr 1, s. 5.

${ }^{50}$ Tamże.
} 
cą się w nim historię. Odkrywanie asyskiego palimpsestu dokonuje się w geście rozpoznania labiryntowej natury miasta.

Figura palimpsestu spotyka się w literaturze z figurą labiryntu, pozwalając znakomicie wyeksponować istotę palimpsestu jako symbolu poznawczej aktywności człowieka. Jak pisze Elżbieta Rybicka:

Powieści labiryntowe ukształtowały [...] swoisty typ postaci literackiej - zagubionej, błądzącej, choć nieustannie poszukującej znaczenia. Bohater $\mathrm{w}$ tradycyjnym realistycznym modelu powieści był niejako człowiekiem pełnym [...], był człowiekiem, który zachował wewnętrzną jedność, stanowiącą odbicie jedności świata i nawet w niekonsekwencji musiał być konsekwentny. Natomiast począwszy od literatury modernistycznej, mimo poszukiwania formuły scalającej, model bohatera pełnego wydaje się nieobecny. Konsekwencją rozbicia jedności podmiotowej i decentracji człowieka jest uczynienie go alogicznym i nieprzewidywalnym. Rządzony sprzecznymi motywacjami, obdarzony mobilnymi cechami, coraz mocniej będzie odczuwał własną sytuację egzystencjalną bądź jako uwięzienie w zamkniętym labiryncie świata, bądź jako zagubienie w błędnych korytarzach czy to rzeczywistości, czy własnej psychiki. [...] Skoro tożsamość nie jest czymś bezspornym i trwałym, to staje się niekiedy zadaniem do wykonania, postulatem i próbą odnalezienia stałego punktu oparcia w rzeczywistości. Stąd modelowanie postaci w powieściach labiryntowych podporządkowane jest niejednokrotnie procesom inicjacyjnym [podkreśl. - DK] $]^{51}$.

Spotkanie wyobraźni palimpsestowej z labiryntową zawsze dokonuje się w przestrzeni naznaczonej kryzysem wiedzy i poznania, o czym przekonują np. rozważania Krzysztofa Mrowcewicza, zawarte w szkicu poświęconym palimpsestowości poezji Mikołaja Sępa Szarzyńskiego. Palimpsestowość tę badacz definiuje jako „zgodę na wieloznaczność”, nie mającą nic wspólnego z hierarchizowaniem, i jako taką właśnie zestawia automatycznie z labiryntem, który nazywa „manierycznym”. Według Mrowcewicza, zawarty w nim „tekst staje się obrazem niepojętego świata, labiryntem bez centrum, do którego wchodzimy nie po to, by wykonać jakieś zadanie, lecz po to, by błądzić" 52 . Tak postrzegany

${ }^{51}$ E. Rybicka, Formy labiryntu w prozie polskiej XX wieku, Kraków 2000, s. 51-54.

${ }^{52}$ K. Mrowcewicz, dz. cyt., s. 29. 
mariaż figury labiryntu i palimpsestu staje się jednocześnie znakiem doświadczenia człowieka żyjącego w czasach, w których upada „ostatecznie tradycyjny obraz świata, rozchodzą się drogi wiedzy i wiary, kończy się raz na zawsze jedność chrześcijaństwa na Zachodzie”, w których rozpoczyna się ,okres sceptycznego zawieszenia głosu, niewiary i niepewności" ‘3. Palimpsestowo-labiryntowa wyobraźnia barokowego poety - zgodnie z założeniem, że „styl jest ściśle związany ze światopoglądem twórcy" ${ }^{54}$ - staje się w tym ujęciu najlepszym świadectwem zagubienia w świecie, którym rządzi niekończące się napięcie między logiką rozumu a potrzebą wiary.

Zarówno barok, jak i wiek XX - jak pisze Michał Głowiński (bazując na pracach Paolo Santarcangelego oraz Gustava René Hockego) ${ }^{55}$ - należą do epok labiryntowych, a literackie labirynty XX wieku równie wyraźnie odsłaniają swoje epistemologiczne zorientowanie. W taki właśnie sposób o labiryncie - jako figurze pokrewnej palimpsestowi - obecnej w pamiętnikach Jerzego Stempowskiego pisze Andrzej Kowalczyk. W szkicu Labirynt. Palimpsest. Dzienniki Jerzego Stempowskiego rekonstruuje właściwe eseiście przeżywanie krajobrazu powojennych zniszczeń, w którym „miasta zburzone stają się labiryntami śmierci, które już niczego nie chronią" ${ }^{56}$.

Ten nowy rodzaj labiryntu nie chroni żadnej tajemnicy, żadnego skarbu, wszystkie jego ścieżki wiodą naprawdę donikąd. Labirynt prawdziwy, również ten, jaki tworzą ulice miasta, świadczy o tym, że przestrzeń została okiełznana przez myśl i wyobraźnię, nad przypadkiem zapanował ład i hierarchia. Zmiażdżone przez bomby i spustoszone przez pożary miasta są dowodem triumfu chaosu, upokorzenia wiary i umysłu, rodza poczucie samotności i melancholii [podkreśl. - DK.] $]^{57}$.

${ }^{53}$ Tamże, s. 25.

54 Tamże, s. 26.

${ }^{55}$ M. Głowiński, Labirynt, [w:] tenże, Mity przebrane. Dionizos. Narcyz. Prometeusz. Marcholt. Labirynt, Kraków 1990, s. 136.

${ }^{56}$ A. S. Kowalczyk, Labirynt. Palimpsest. Dzienniki Jerzego Stempowskiego, „Przegląd Polityczny" 2000, nr 45, s. 63.

57 Tamże, s. 59. 
Brak odczucia labiryntowego centrum wyraża pustkę świata, który poddał się wyjaławiającemu kataklizmowi wojny. Błądzenie po labiryncie oddaje całą skalę napięcia, które staje się udziałem człowieka rozpoznającego ogrom wojennego wyniszczenia, poszukującego odpowiedzi na dręczące go pytania, tworząc w pamiętnikach Stempowskiego grunt dla użycia metafory palimpsestu. Ona bowiem w tym świecie ruin umożliwia ,zstąpienie do głębi”, „pozwala obcować z tajemnicą dziejów, zagadką nieuchronnej przemiany życia w kamień, chwili w wieczność, światła w mrok podziemi" ${ }^{58}$. Użycie palimpsestowej figury wyobraźni w pamiętnikach Stempowskiego pozwala - zdaniem Kowalczyka - rozpoznać i rozróżnić porządek kultury i natury. Porównanie dwóch palimpsestów - tego utworzonego przez cywilizację i tego będącego wynikiem przemian zachodzących w porządku natury - doprowadza do stwierdzenia, że

Pierwszy jest linearny, ciągły, konserwujący; drugi jest alternacją katastrof i okresów rozkwitu. Kultura skrzętnie zachowuje i powtarza; natura rozrzutnie niszczy i odtwarza. Pierwsza może polegać tylko na pamięci, naśladowaniu i powtórzeniu; druga zna tajemnicę regeneracji, głębinowym mocom destrukcji odpowiadają siły życia, śmierci - spontaniczne odrodzenie życia z popiołu ${ }^{59}$.

Palimpsestowa wyobraźnia - spokrewniona z figurą labiryntu nie tylko służy refleksji o zatracie wartości, ale przede wszystkim pozwala poznać logikę ich odradzania się, ocenić szanse ich rekonstrukcji.

Etyczna natura palimpsestowej wyobraźni, jej epistemologiczne zorientowanie w szczególny sposób otwiera perspektywę mówienia o niej jako kategorii młodopolskiej świadomości, choć - jak widać z przytoczonych rozważań na temat pamiętników Stempowskiego czy też nie skomentowanych $\mathrm{w}$ tym artykule, a również istotnych dla niniejszego zagadnienia dywagacji o ,palimpsestowym” Gombrowiczu ${ }^{60}$

\footnotetext{
${ }^{58}$ Tamże, s. 63.

59 Tamże.

${ }^{60}$ Por. M. Bielecki, Gombrowicz palimpsestowy, „Teksty Drugie” 2005, nr 3, s. 104-108. O tym, jak palimpsest stał się pojemną metaforą współczesnego przeżywania świata świadczą
} 
- problem ten w gruncie rzeczy nie powinien chronologicznie zawężać się tylko do początku XX wieku. Trzeba pamiętać, że potraktowanie palimpsestowej wyobraźni jako klucza do kulturowej świadomości otwiera badawczą refleksję na różne warianty dwudziestowiecznych transpozycji palimpsestowej wyobraźni - funkcjonalizującej się znakomicie w kontekstach autotematycznych rozważań o naturze poezji ${ }^{61}$, refleksji o tożsamości egzystencjalneje ${ }^{62}$ czy też formach współczesnej kultury ${ }^{63}$. Jak napisał Andrzej Kijowski, „każda kultura tworzy własną figurę procesu myślowego" ${ }^{64}$. Dla Rybickiej „taką figurą dla rzeczywistości nowoczesnej będzie w głównej mierze labirynt i motywy błądzenia" ${ }^{65}$. W kontekście powyższych rozważań za figurę taką równie dobrze można byłoby uznać także wyobrażenie palimpsestu, które wyraźnie spotyka się z wyobraźnią labiryntową. Palimpsest, podobnie jak labirynt, unaocznia przekonanie o chaosie świata i jego potencjalnym porządku. Mobilizuje do stawiania pytań o możliwości poznawcze człowieka, „o znaczenie tradycji, o kondycję inteligencji, o ciągłość

też inne wypowiedzi: S. Nowak, „Novi Jerusalim” Borislava Pokicia jako palimpsest, „Pamiętnik Słowiański” 2002, t. 52, z. 1, s. 37-50; M. Halicki, Palimpsest, „Kino” 2006, nr 9, s. 76; M. Oleszczyk, Palimpsest Terence'a Daviesa: „Dalekie glosy, martwe natury”, „Kwartalnik Filmowy” 2006, nr 53, s. 60-66; J. Gondowicz, Palimpsest Eldorado, „Twórczość” 2007, nr 1, s. 144-147; J. Wierzejska, Autoportret palimpsestowy, „Nowe Książki” 2007, nr 1, s. 47; G. E. Karpińska, Palimpsestowe oblicze miasta: przyklad Łodzi przemystowej, „Ochrona Zabytków" 2004, nr 3-4, s. 127-140.

${ }^{61}$ Zob. np. R. Bąk, Palimpsest, „Topos” 1998, nr 1/2, s. 76: „Poezja jest słowem. Używa słów. Jeśli dąży do prawdy, do istoty rzeczy - ufam jej słowom. Ale same słowa nie są jeszcze poezją. Stają się nią, kiedy wyłania się z nich obraz. Obraz-metafora podnosi zwykły opis rzeczy na poziom wyższy. Ale by to osiagnąć, musi zejść najniżej, pod powierzchnię tego, co namacalne; musi zgłębić życie. Łączy ona wówczas w sobie kilka warstw rzeczywistości. Staje się palimpsestem".

${ }^{62}$ Zob. K. Wierzyński, Palimpsest, [w:] tenże, Poezja, Kraków 1981, s. 337.

${ }^{63}$ Zob. np. G. Niziołek, Apokryfy i palimpsesty (Teatr Krystiana Lupy; cz. 2), „Dialog” 1996, nr 8, s. 134-144; B. Kita, Telewizyjny palimpsest, „Kwartalnik Filmowy” 201, nr 35/36, s. 152159; D. Kołodziejczyk, W poetyce palimpsestu. O Wspólnocie Kulturowej „Borussia”, „Sprawy Narodowościowe" 2000, z. 16-17, s. 205-208; Jorge Machín Lucas, Region jako palimpsest, thum. B. Jaroszuk, „Literatura na Świecie” 2007, nr 1-2, s. 56-65; A. Rogoś, Palimpsest Muzeum, „Orońsko" 2004, nr 4, s. 40-43.

${ }^{64}$ E. Rybicka, dz. cyt., s. 56.

${ }^{65}$ Tamże. 
z przeszłością i przyszłością. Podejmuje równocześnie istotny dla literatury modernistycznej problem zdobywania świadomości" ${ }^{66}$. Można powiedzieć, że służy tym samym pytaniom, które ujawniają się w perspektywie wyobrażenia labiryntu, z tą tylko różnica, że czyni je częścią kryzysowego doświadczenia świata. Wskazując na najistotniejsze problemy dwudziestowiecznej świadomości, w jakiś sposób tłumaczy jednocześnie ich genezę.

${ }^{66}$ Tamże, s. 100. 